Int. J. Electrochem. Sci., 11 (2016) $6862-6872$

\title{
Electrochemical Detection of Codeine in Pharmaceutical Tablets Using a Tungsten Oxide Nanoparticles and Carbon Nanotubes Modified Electrode
}

\author{
Qian $\mathrm{Yu}^{l, *}$, Xianhui Yang ${ }^{2}$, Yan Chen $^{1}$ \\ ${ }^{1}$ Department of pharmacy, People's Hospital of Zhengzhou, No.33 the Yellow River Road, \\ Zhengzhou, Henan, 450053, P. R. China \\ ${ }^{2}$ Zhengzhou Railway Vocational and Technical College, No.2 the Xingfu Road, Two Seven District, \\ Zhengzhou, Henan, 450000, P. R. China \\ *E-mail: qianyu_zph@yeah.net
}

doi: $10.20964 / 2016.08 .13$

Received: 4 May 2016 / Accepted: 25 May 2016 / Published: 7 July 2016

\begin{abstract}
An electrochemical sensor with a glassy carbon electrode (GCE) decorated with a composite of carbon nanotubes (CNTs) and tungsten oxide $\left(\mathrm{WO}_{3}\right)$ was prepared for the quantification of codeine. The crystal structure of the $\mathrm{CNT}-\mathrm{WO}_{3}$ composite was characterized by X-ray powder diffraction (XRD) and the morphology by scanning electron microscopy (SEM). In comparison with bare GCE, $\mathrm{WO}_{3}$ modified GCE and CNT modified GCE, the CNT- $\mathrm{WO}_{3}$ composite modified GCE revealed a welldefined oxidation of codeine. Besides, the current response exhibited a remarkable enhancement during the oxidation process. The current response of codeine oxidation peak is linearly related with the codeine concentration ranging from 0.005 to $20 \mu \mathrm{M}$ with the detection limit of $0.02 \mu \mathrm{M}$. The improved voltametric behaviour and long-time stability of the electrochemical sensor make it successfully applied for codeine determination in the medicament and human urine.
\end{abstract}

Keywords: Electrochemical sensor; Codeine; Carbon nanotubes; Tungsten oxide nanoparticles; Oxidation

\section{$\underline{\text { FULLTEXT }}$}

(C) 2016 The Authors. Published by ESG (www.electrochemsci.org). This article is an open access article distributed under the terms and conditions of the Creative Commons Attribution license (http://creativecommons.org/licenses/by/4.0/). 